\title{
Devitrification of rapidly quenched Al-Cu-Ti amorphous alloys
}

\author{
D K MISRA, R S TIWARI and O N SRIVASTAVA* \\ Department of Physics, Banaras Hindu University, Varanasi 221 005, India
}

MS received 6 January 2003

\begin{abstract}
X-ray diffraction, transmission electron microscopy and differential scanning calorimetry were carried out to study the transformation from amorphous to icosahedral/crystalline phases in the rapidly quenched $\mathrm{Al}_{50} \mathrm{Cu}_{45} \mathrm{Ti}_{5}$ and $\mathrm{Al}_{45} \mathrm{Cu}_{45} \mathrm{Ti}_{10}$ alloys. In the present investigation, we have studied the formation and stability of amorphous phase in $\mathrm{Al}_{50} \mathrm{Cu}_{45} \mathrm{Ti}_{5}$ and $\mathrm{Al}_{45} \mathrm{Cu}_{45} \mathrm{Ti}_{10}$ rapidly quenched alloys. The DSC curve shows a broad complex type of exothermic overlapping peaks $\left(288-550^{\circ} \mathrm{C}\right)$ for $\mathrm{Al}_{50} \mathrm{Cu}_{45} \mathrm{Ti}_{5}$ and a well defined peak around $373^{\circ} \mathrm{C}$ for $\mathrm{Al}_{45} \mathrm{Cu}_{45} \mathrm{Ti}_{10}$ alloy. In the case of $\mathrm{Al}_{50} \mathrm{Cu}_{45} \mathrm{Ti}_{5}$ alloy amorphous to icosahedral phase transformation has been observed after annealing at $280^{\circ} \mathrm{C}$ for $73 \mathrm{~h}$. Large dendritic growth of icosahedral phase along with $\alpha$-Al phase has been found. Annealing of $\mathrm{Al}_{50} \mathrm{Cu}_{45} \mathrm{Ti}_{5}$ alloy at $400^{\circ} \mathrm{C}$ for $8 \mathrm{~h}$ results in formation of $\mathrm{Al}_{3} \mathrm{Ti}$ type phase. $\mathrm{Al}_{45} \mathrm{Cu}_{45} \mathrm{Ti}_{10}$ amorphous alloy is more stable in comparison to $\mathrm{Al}_{50} \mathrm{Cu}_{45} \mathrm{Ti}_{5}$ alloy and after annealing at $4_{00}^{\circ} \mathrm{C}$ for $8 \mathrm{~h}$ it also transforms to $\mathrm{Al}_{3} \mathrm{Ti}$ type phase. However, this alloy does not show amorphous to icosahedral phase transformation.
\end{abstract}

Keywords. Amorphous phase; icosahedral phase; crystallization.

\section{Introduction}

In recent years there has been spurt of studies relating to amorphous to quasicrystalline transformation due to its scientific as well as technological significance (Greer et al 2001; Inoue et al 2001). On one hand these studies have been undertaken to throw light on the formation mechanism of the icosahedral phase and the correlation between quasicrystalline phase and local structure of the glassy alloys and on the other hand improved mechanical properties of partially nanoquasicrystalline phase in glassy matrix have aroused considerable interest from application point of view (Fasi et al 2001; Aronim et al 2001; Li et al 2001; Satyanarayana et al 2001; Srinivasan and Chattopadhyay 2001; Hambleton et al 2001). Large number of alloys exhibiting glass to quasicrystalline transformation have been broadly classified into Zr-based, Ti-based, Hf-based and Al-based alloys. Amongst these alloys $\mathrm{Al}-\mathrm{Cu}-\mathrm{V}$ system has been of special interest because this belongs to $\mathrm{Al}-\mathrm{Cu}-3 d-\mathrm{TM}$ series of alloys which have been systematically studied and show chemical dependence of stability of amorphous, icosahedral and decagonal phases (Popescu et al 1995). For example, as atomic number of transition metal increases in these alloys, the as quenched alloy exhibits amorphous phase $(\mathrm{Al}-\mathrm{Cu}-\mathrm{V})$, metastable $(\mathrm{Al}-\mathrm{Cu}-\mathrm{Cr}, \mathrm{Al}-\mathrm{Cu}-\mathrm{Mn})$ and stable $(\mathrm{Al}-\mathrm{Cu}-\mathrm{Fe})$ icosahedral phases and stable decagonal phase $(\mathrm{Al}-\mathrm{Cu}-\mathrm{Co})$.

\footnotetext{
*Author for correspondence
}

The Al-Cu-V system which was shown by Tsai et al (1999) to form an amorphous phase has been extensively investigated with regard to crystallization and structural similarity between amorphous and quasicrystalline phases (Holzer and Kelton 1991; Tsai et al 1999). Upadhya and Tiwari (1996) investigated growth of the quasicrystalline and related crystalline phases in $\mathrm{Al}_{65} \mathrm{Cu}_{20} \mathrm{~V}_{15}$ alloy and have pointed out the role of electron concentration $(e / a)$ in the stabilization of amorphous and icosahedral phases. Misra et al (2001) reported the effect of Fe substitution on the stability and microstructure of icosahedral phase in $\mathrm{Al}-\mathrm{Cu}-\mathrm{V}$ alloy system. Since $\mathrm{V}$ and $\mathrm{Ti}$ are neighbouring transition metals in periodic table and are very similar in their atomic sizes, therefore, Ti may be chosen as an appropriate substitution element in place of $\mathrm{V}$ in $\mathrm{Al}-\mathrm{Cu}-\mathrm{V}$ alloy in order to stabilize amorphous phase. In passing it may be mentioned that the alloy system Al-Ti (in which $\mathrm{Cu}$ is absent) exhibits amorphous phase which after subsequent annealing transforms to crystalline phases (Murty et al 1992). Also, different crystalline phases in $\mathrm{Al}-\mathrm{Ti}-\mathrm{V}$ alloy system have been recently investigated (Shao et al 1995). However, no study pertaining to amorphous to quasicrystalline/crystalline phase transformation in $\mathrm{Al}-\mathrm{Cu}-\mathrm{Ti}$ system has been reported so far. The present work is also important due to the fact that out of various $\mathrm{Al}-\mathrm{Cu}-3 d-\mathrm{TM}$ alloys, information regarding the stabilization of quasicrystalline phase in $\mathrm{Al}-\mathrm{Cu}-\mathrm{Ti}$ alloy system is still missing. The aim of the present investigation is to report the results of investigation of formation of amorphous phase and transformation from amorphous to quasicrystalline/crystalline phases in $\mathrm{Al}-\mathrm{Cu}-\mathrm{Ti}$ alloys 
employing X-ray diffraction, transmission electron microscopy and differential scanning calorimetry (DSC) techniques. It may be mentioned that the stoichiometry (composition) of the alloys has been chosen, so that the electron concentration $(e / a)$ of the alloy is close to that of $\mathrm{Al}_{75} \mathrm{Cu}_{15} \mathrm{~V}_{10}$ which is known to exhibit amorphous phase.

\section{Experimental}

The $\mathrm{Al}_{50} \mathrm{Cu}_{45} \mathrm{Ti}_{5}$ and $\mathrm{Al}_{45} \mathrm{Cu}_{45} \mathrm{Ti}_{10}$ alloys were prepared by melting highly pure, $\mathrm{Al}, \mathrm{Cu}$ and $\mathrm{Ti}$ in an induction furnace, in the presence of dry argon atmosphere. The ingots formed were re-melted several times to ensure homogeneity. The homogenized ingots were placed in a quartz nozzle of $\sim 1 \mathrm{~cm}$ internal diameter with a circular orifice of $\sim 1 \mathrm{~mm}$ diameter and then melt-spun onto a Copper wheel ( $14 \mathrm{~cm} \mathrm{dia)} \mathrm{rotating} \mathrm{at} \mathrm{a} \mathrm{speed} \mathrm{of} \mathrm{about}$ $40 \mathrm{~m} / \mathrm{s}$. During melt-spinning, the entire apparatus was enclosed in a steel enclosure through which argon gas was made to flow continuously at an over pressure of $5 \mathrm{MPa}$ so as to prevent oxidation of the ribbons after ejection from the nozzle. The density measurements were performed by archimedean method. A single pan precision balance with sensitivity of $0.001 \mathrm{mg}$ was employed. Samples used weighed about $1 \mathrm{~g}$.

The gross structural characterization was done by employing a X-ray diffractometer (Philips PW-1710) with graphite monochromator and $\mathrm{CuK}_{\alpha}$ radiation. The experimental conditions and parameters (scan speed, cooling speed etc) were kept constant for all diffraction experiments performed on different samples. The ribbons were thinned using an electrolyte, 67\% methanol and 33\% nitric acid, at $-20^{\circ} \mathrm{C}$. The samples thus prepared were studied by TEM using a Philips CM-12 electron microscope. The crystallization behaviour of these amorphous alloys has been studied using DSC 2910 (TA Instruments Inc. USA) system in modulated DSC mode.

\section{Results and discussion}

Figures $1 \mathrm{a}-\mathrm{b}$ show XRD traces obtained from the as melt-spun alloys, $\mathrm{Al}_{50} \mathrm{Cu}_{45} \mathrm{Ti}_{5}$ and $\mathrm{Al}_{45} \mathrm{Cu}_{45} \mathrm{Ti}_{10}$. Both the traces show the broad amorphous peak around an angle $43 \cdot 5^{\circ}$. The subtle differences in the broad peaks (e.g. width of the peak and peak position) corresponding to the two alloys may be noticed. These differences may be due to the different types of short range ordering in these alloys. One of the methods to assess the stability of an amorphous alloy is to use DSC to measure the temperature at which the amorphous phase starts to crystallize. Figure 2 shows the DSC curve taken corresponding to the alloy $\mathrm{Al}_{50} \mathrm{Cu}_{45} \mathrm{Ti}_{5}$ with the heating rate of $5^{\circ} \mathrm{C} / \mathrm{min}$. The DSC curve corresponding to this alloy contains a wide exothermic peak extending from $288^{\circ} \mathrm{C}$ to $550^{\circ} \mathrm{C}$. This wide peak consists of two overlapping maxima at least. The peak temperature of two peaks are $393^{\circ} \mathrm{C}$ and $440^{\circ} \mathrm{C}$, respectively. Figure 3 shows DSC curve corresponding to the alloy $\mathrm{Al}_{45} \mathrm{Cu}_{45} \mathrm{Ti}_{10}$ with the same heating rate. The DSC curve corresponding to this alloy contains only one exothermic peak at temperature $373^{\circ} \mathrm{C}$. The onset of this peak is at relatively higher temperature $\left(347^{\circ} \mathrm{C}\right)$ and thus indicates higher stability of this amorphous alloy in comparison to $\mathrm{Al}_{50} \mathrm{Cu}_{45} \mathrm{Ti}_{5}$. Figures $4 \mathrm{a}-\mathrm{b}$ show XRD traces of $\mathrm{Al}_{50} \mathrm{Cu}_{45} \mathrm{Ti}_{5}$ alloy obtained from isothermal annealing of the sample at $280^{\circ} \mathrm{C}$ for $73 \mathrm{~h}$ and $400^{\circ} \mathrm{C}$ for $8 \mathrm{~h}$, respectively. The XRD patterns corresponding to $\mathrm{Al}_{50} \mathrm{Cu}_{45} \mathrm{Ti}_{5}$ amorphous alloy annealed at $280^{\circ} \mathrm{C}$ shows only peaks which can be identified as a mixture of crystalline $\alpha$-Al and icosahedral phases. The identification of icosahedral phase was made on the basis of six independent miller indices proposed by Elser (1985). The $\mathrm{Al}_{50} \mathrm{Cu}_{45} \mathrm{Ti}_{5}$ alloy when annealed at $400^{\circ} \mathrm{C}$ i.e. near the strong exothermic DSC peak $\left(\sim 393^{\circ} \mathrm{C}\right)$ for $8 \mathrm{~h}$, shows only diffraction peaks which have been identified as the $\mathrm{Al}_{3}$ Ti-type tetragonal phase with lattice parameter, $a=3.84 \AA, c=$

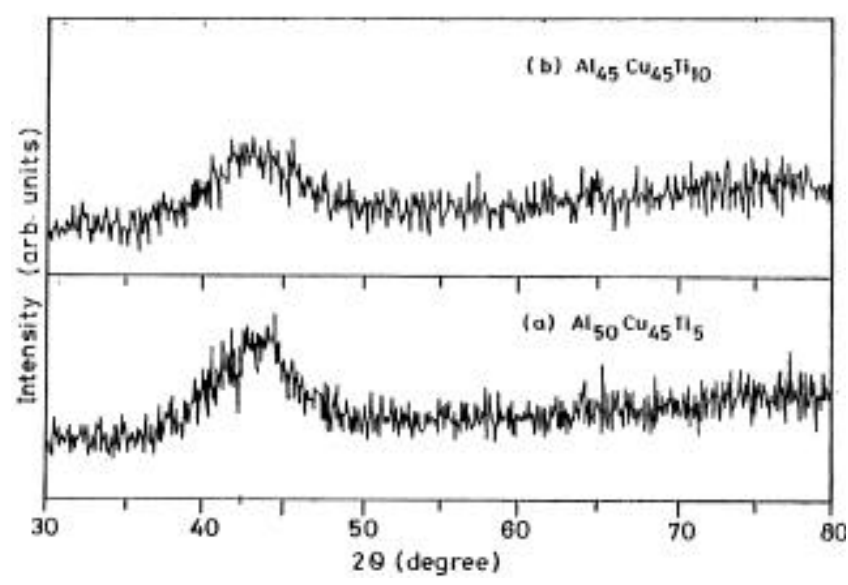

Figure 1. X-ray powder diffraction patterns of the as-quenched (a) $\mathrm{Al}_{50} \mathrm{Cu}_{45} \mathrm{Ti}_{5}$ and (b) $\mathrm{Al}_{45} \mathrm{Cu}_{45} \mathrm{Ti}_{10}$ alloys. $\mathrm{CuK}_{\alpha}$ radiation was employed with $\lambda=0 \cdot 154 \mathrm{~nm}$ and $2 \theta$ scanning rate of $0 \cdot 05 / \mathrm{s}$.

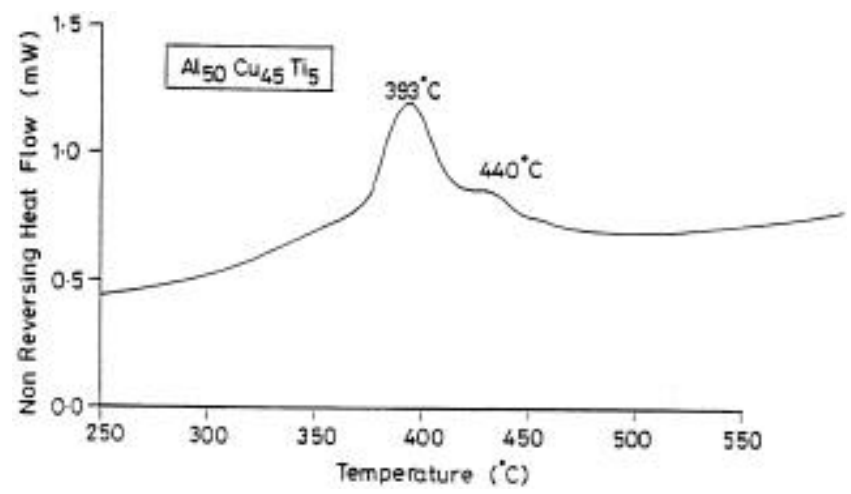

Figure 2. Differential scanning calorimeter curve of $\mathrm{Al}_{50} \mathrm{Cu}_{45} \mathrm{Ti}_{5}$ amorphous alloy at scanning rate $5^{\circ} \mathrm{C} / \mathrm{min}$. 


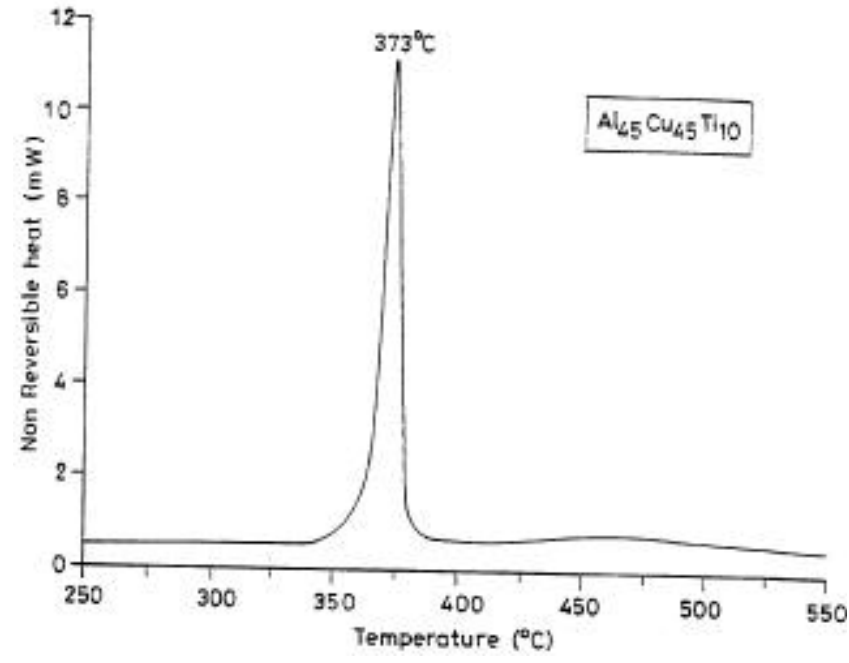

Figure 3. Differential scanning calorimeter (DSC) curve of $\mathrm{Al}_{45} \mathrm{Cu}_{45} \mathrm{Ti}_{10}$ amorphous alloy at scanning rate $5^{\circ} \mathrm{C} / \mathrm{min}$.

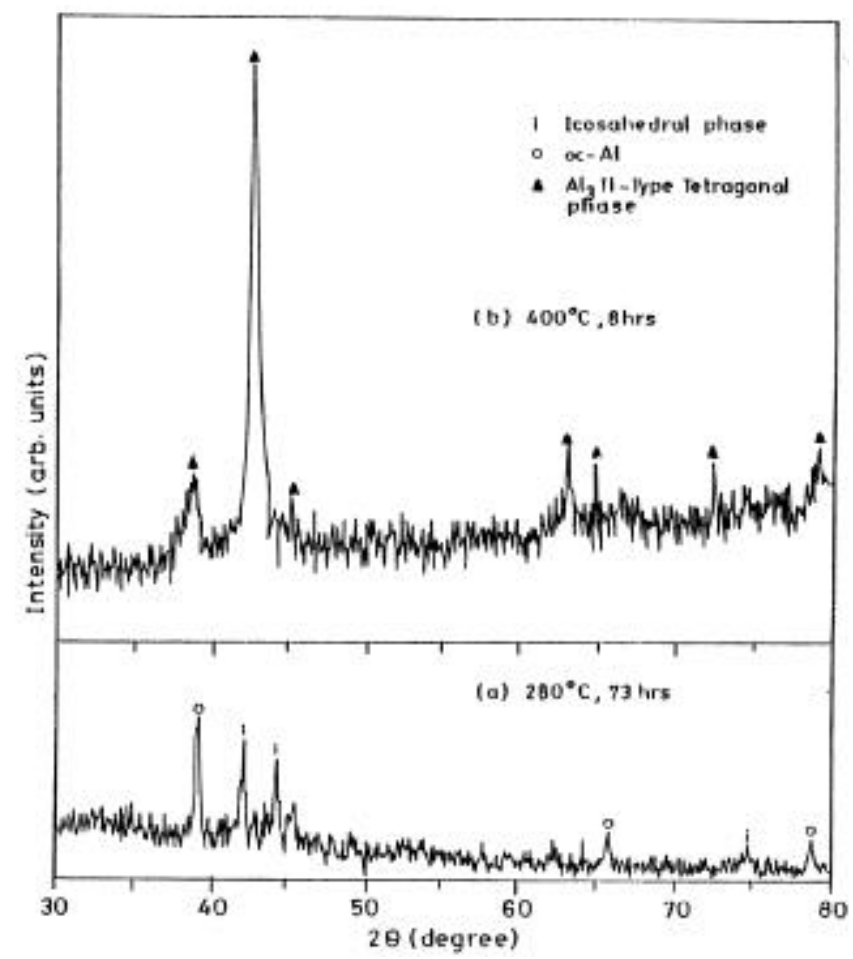

Figure 4. X-ray diffraction patterns of $\mathrm{Al}_{50} \mathrm{Cu}_{45} \mathrm{Ti}_{5}$ alloy annealed in vacuum $\left(10^{-6}\right.$ torr) at (a) $280^{\circ} \mathrm{C}$ for $73 \mathrm{~h}$ showing $\alpha$-Al and icosahedral phases and (b) $400^{\circ} \mathrm{C}$ for $8 \mathrm{~h}$ showing the presence of $\mathrm{Al}_{3} \mathrm{Ti}$ type tetragonal phase.

8.61 $\AA$ (figure 4b). The above observation clearly indicates that in the first stage, amorphous alloy $\mathrm{Al}_{50} \mathrm{Cu}_{45} \mathrm{Ti}_{5}$ starts transforming to icosahedral and $\alpha-\mathrm{Al}$ phases around $280^{\circ} \mathrm{C}$. At $400^{\circ} \mathrm{C}, \alpha-\mathrm{Al}$ and icosahedral phases transform to $\mathrm{Al}_{3} \mathrm{Ti}$ type tetragonal phase. The $\mathrm{X}$-ray diffraction profile of the alloy, $\mathrm{Al}_{45} \mathrm{Cu}_{45} \mathrm{Ti}_{10}$, annealed at $400^{\circ} \mathrm{C}$ for $8 \mathrm{~h}$ is similar to figure $4 \mathrm{~b}$ and shows only $\mathrm{Al}_{3} \mathrm{Ti}$ type phase.
Thus the change in the structure of amorphous $\mathrm{Al}_{50} \mathrm{Cu}_{45} \mathrm{Ti}_{5}$ and $\mathrm{Al}_{45} \mathrm{Cu}_{45} \mathrm{Ti}_{10}$ alloys may be summarized as follows.

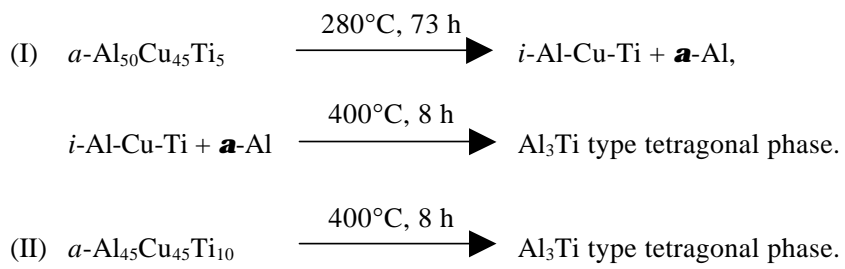

For an unambiguous identification of the icosahedral phase and morphological details of different phases, these alloys have been investigated employing transmission electron microscopic techniques. Figure 5a depicts a representative microstructure of $\mathrm{Al}_{50} \mathrm{Cu}_{45} \mathrm{Ti}_{5}$ alloy annealed at $280^{\circ} \mathrm{C}$ for $73 \mathrm{~h}$. The microstructure reveals large dendritic type morphology which is growing radially from the centre of the grains. The average size of these dendritic grains are $\sim 1.5 \mu \mathrm{m}$. The selected area diffraction patterns corresponding to dendritic morphology are shown in figure $5 \mathrm{~b}$ (i-iii). These SAD patterns correspond to five-fold, three-fold and two-fold of icosahedral phase. It is worthwhile to mention that as the $\mathrm{Ti}$ concentration in $\mathrm{Al}-\mathrm{Cu}-\mathrm{Ti}$ system is increased e.g. in $\mathrm{Al}_{45} \mathrm{Cu}_{45} \mathrm{Ti}_{10}$ alloy, it still exhibits amorphous phase. However, the amorphous phase in this alloy is more stable and it transforms directly to $\mathrm{Al}_{3} \mathrm{Ti}$ type phase without transforming to icosahedral phase as in the case of $\mathrm{Al}_{50} \mathrm{Cu}_{45} \mathrm{Ti}_{5}$ alloy. Figure 6 a shows microstructure corresponding to $\mathrm{Al}_{45} \mathrm{Cu}_{45} \mathrm{Ti}_{10}$ alloy annealed at $400^{\circ} \mathrm{C}$ for $8 \mathrm{~h}$. The nanosized crystals of $\mathrm{Al}_{3} \mathrm{Ti}$ type phase can easily be noticed. The SAD pattern corresponding to this region is shown in figure 6b. The indexing of powder lines indicates that transformed phase is $\mathrm{Al}_{3} \mathrm{Ti}$ type tetragonal phase. At this stage the exact mechanism of the transformation from amorphous to icosahedral phase/crystalline phase with increasing $\mathrm{Ti}$ concentration is not known, but the formation and stability of amorphous phase in both the alloys may be due to their electronic structure. It is well known that in HumeRothery alloys, Fermi surface-Brillouin zone (FS-BZ) interaction leads to the stabilization of electron phases. It can be seen here that the amorphous phase formed for the compositions $\mathrm{Al}_{50} \mathrm{Cu}_{45} \mathrm{Ti}_{5}$ and $\mathrm{Al}_{45} \mathrm{Cu}_{45} \mathrm{Ti}_{10}$ is behaving as an electron phase. By using valencies +3 for $\mathrm{Al}$, +1 for $\mathrm{Cu}$ and +4 for $\mathrm{Ti}$ as proposed earlier (Smith and Ray 1957; Raynor 1994) for crystalline Al-TM alloys, one calculates the electron concentration, ela, to be $2 \cdot 15$ and 2.20 for $\mathrm{Al}_{50} \mathrm{Cu}_{45} \mathrm{Ti}_{5}$ and $\mathrm{Al}_{45} \mathrm{Cu}_{45} \mathrm{Ti}_{10}$, respectively. According to free electron model, the Fermivector is given by

$$
k_{\mathrm{F}}=\left[3 \pi^{2} e / a / V\right]^{1 / 3},
$$

where $V$ is the average atomic volume. The values of $k_{\mathrm{F}}$ calculated for the two amorphous alloys are given in table 1 . 

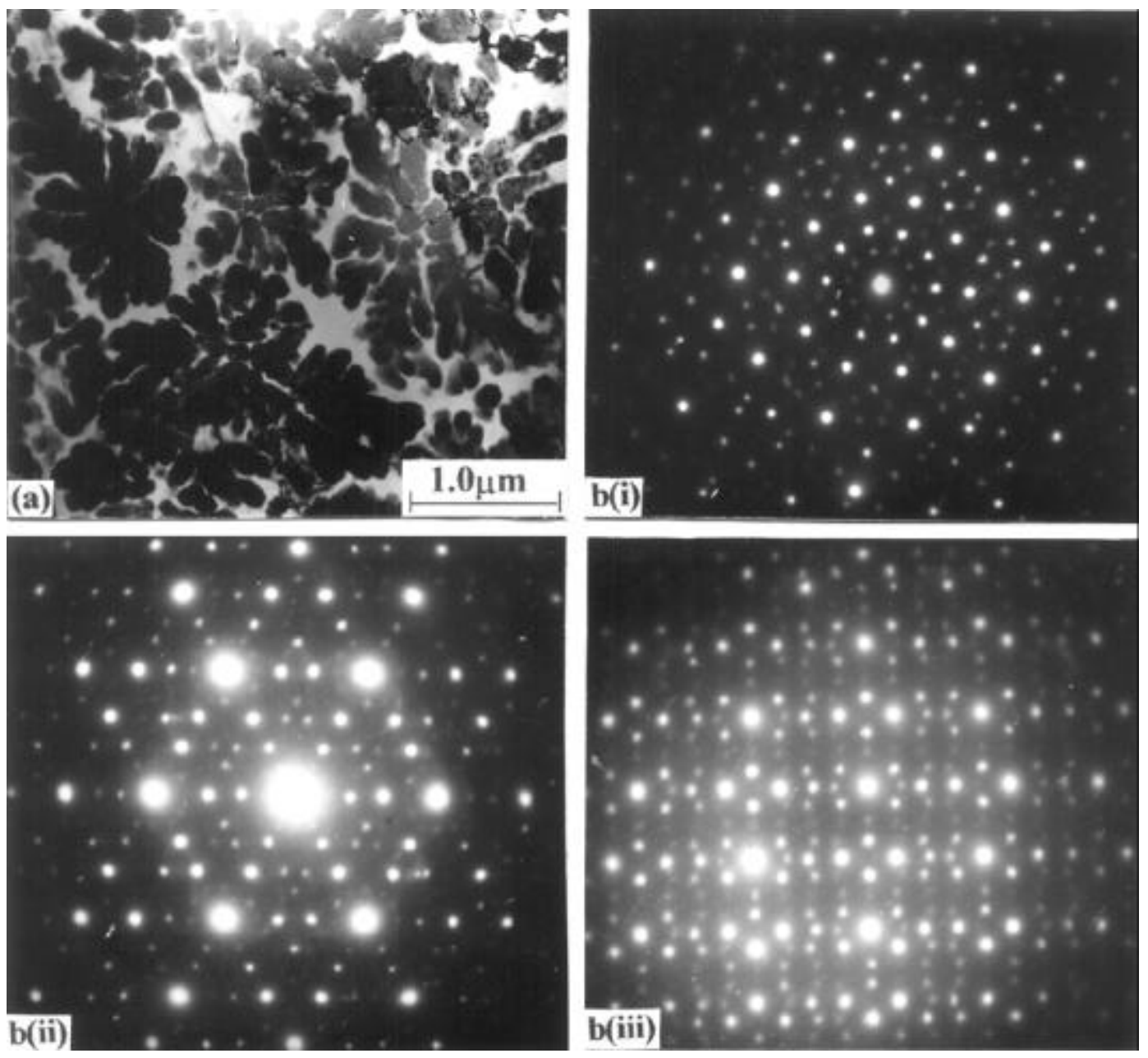

Figure 5. (a) Electron micrograph showing large dendritic icosahedral grains and (b) selected area diffraction (SAD) patterns exhibiting (i) five-fold, (ii) three-fold and (iii) two-fold axes parallel to electron beam corresponding to large dendritic grains.

The reciprocal vectors corresponding to the maximum peak intensity for amorphous phase in $\mathrm{Al}_{50} \mathrm{Cu}_{45} \mathrm{Ti}_{5}$ and $\mathrm{Al}_{45} \mathrm{Cu}_{45} \mathrm{Ti}_{10}$ alloys as determined from XRD are $30 \cdot 7$ and $29.70 \mathrm{~nm}^{-1}$, respectively. The parameters used to calculate $k_{\mathrm{P}} / 2 k_{\mathrm{F}}$ for amorphous is given in table 1 . It can easily be discerned that for these two alloys the ratio $k_{\mathrm{P}} / 2 k_{\mathrm{F}}$ remains nearly equal to unity and consequently amorphous phase gets stabilized. However, it is quite intriguing that unlike $\mathrm{Al}_{45} \mathrm{Cu}_{45} \mathrm{Ti}_{10}$ amorphous alloy which directly transforms to $\mathrm{Al}_{3}$ Ti-type phase, $\mathrm{Al}_{50} \mathrm{Cu}_{45} \mathrm{Ti}_{5}$ amorphous alloy initially transforms to icosahedral phase. At this stage it is not clear why these two alloys which have nearly same electron concentration, ela (table 1), behave differently in regard to amorphous to icosahedral phase transformation. A plausible explanation may be given in terms of hindrance of nucleation of icosahedral phase in $\mathrm{Al}_{45} \mathrm{Cu}_{45} \mathrm{Ti}_{10}$ alloy. Even in $\mathrm{Al}_{50} \mathrm{Cu}_{45} \mathrm{Ti}_{5}$ alloy, large size of icosahedral grains (figure 5a) indicates that nucleation rate is low thus allowing the growth of icosahedral grains before impingement. However, with slight variation in stoichiometry (e.g. in $\mathrm{Al}_{45} \mathrm{Cu}_{45} \mathrm{Ti}_{10}$ ), the nucleation rate of icosahedral phase might be considerably reduced. This would result in the transformation of amorphous phase in $\mathrm{Al}_{45} \mathrm{Cu}_{45} \mathrm{Ti}_{10}$ alloy to $\mathrm{Al}_{3} \mathrm{Ti}$ type phase. Further investigations would be required to get insight of the factors which govern the nucleation of icosahedral phase in these amorphous alloys. It should be mentioned that as in the case of $\mathrm{Al}-\mathrm{Cu}-\mathrm{V}$ alloy, Al-Cu-Ti alloy also exhibits amorphous to icosahedral phase transformation. In comparison to $\mathrm{Al}-\mathrm{Cu}-\mathrm{V}$, however, the morphology of icosahedral phase in the present case is more dendritic in nature. The present investigation also indicates that the stability of icosahedral phase in $\mathrm{Al}-\mathrm{Cu}-3 d-\mathrm{TM}$ alloy series increases with increasing atomic number of transition metal as has been pointed out earlier for $\mathrm{TM}=\mathrm{V}$, Cr, Mn, Fe (Popescu et al 1995). Thus the chemical dependence of the stability of icosahedral phase in $\mathrm{Al}-\mathrm{Cu}-3 d-\mathrm{TM}$ series becomes further evident from the present work. 

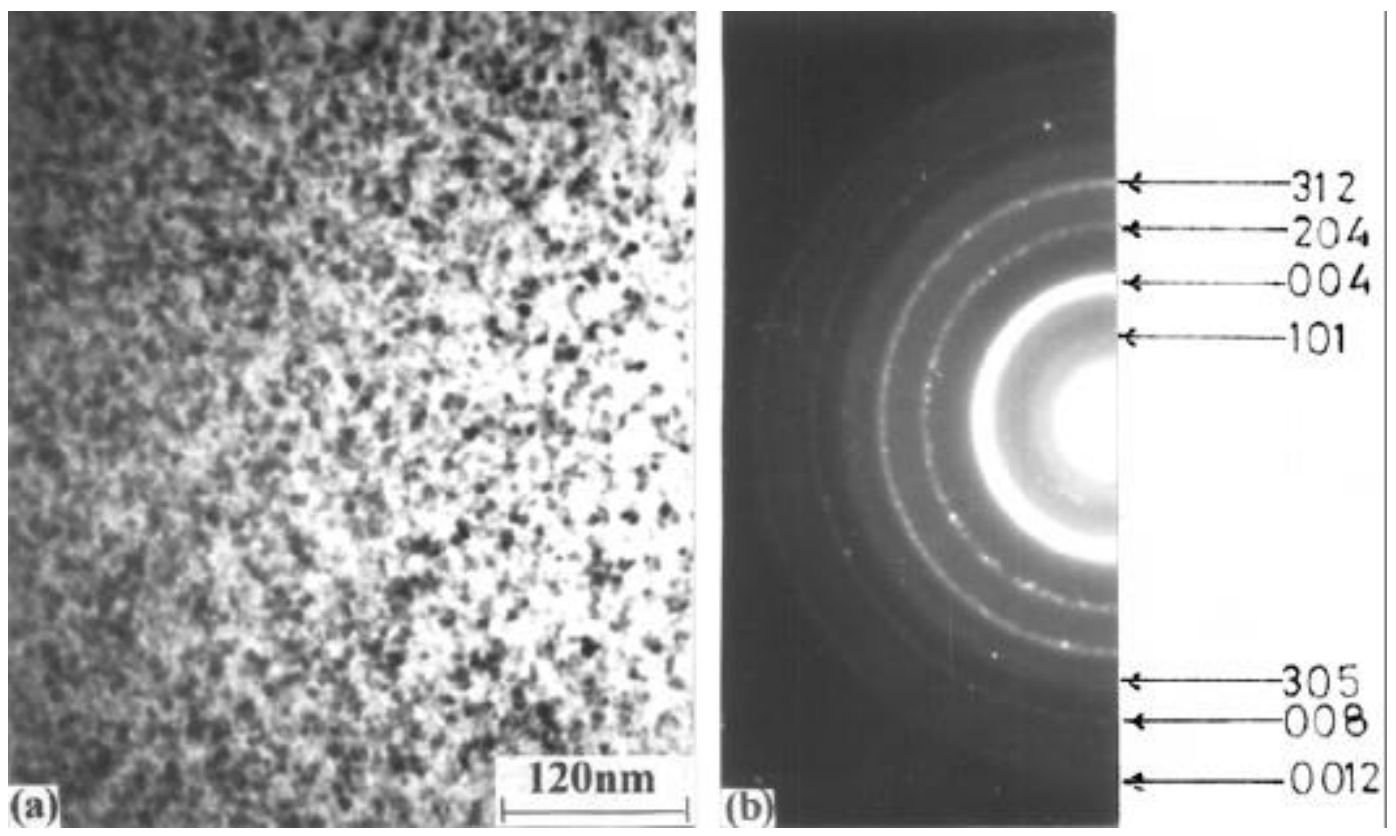

Figure 6. (a) Nano-sized electron micrograph corresponding to $\mathrm{Al}_{3} \mathrm{Ti}$-type tetragonal phase and (b) powder ring corresponding to nano-sized grain which has been indexed with $\mathrm{Al}_{3}$ Ti-type tetragonal phase.

Table 1. Density, $\rho$, electron concentration ela, Fermi wave vector, $k_{\mathrm{F}}$, and reciprocal vector, $k_{\mathrm{P}}$, for amorphous phase.

\begin{tabular}{lcc}
\hline Alloy phase & $\begin{array}{c}\mathrm{Al}_{50} \mathrm{Cu}_{45} \mathrm{Ti}_{5} \\
\text { (amorphous) }\end{array}$ & $\begin{array}{c}\mathrm{Al}_{45} \mathrm{Cu}_{45} \mathrm{Ti}_{10} \\
\text { (amorphous) }\end{array}$ \\
\hline$\rho\left(\mathrm{g} / \mathrm{cm}^{3}\right)$ & $3 \cdot 84$ & $3 \cdot 56$ \\
$e / a$ & $2 \cdot 15$ & $2 \cdot 20$ \\
$2 k_{\mathrm{F}}\left(\mathrm{nm}^{-1}\right)$ & $29 \cdot 74$ & $29 \cdot 05$ \\
$k_{\mathrm{P}}\left(\mathrm{nm}^{-1}\right)$ & $30 \cdot 7$ & $29 \cdot 7$ \\
$k_{\mathrm{P}} / 2 k_{\mathrm{F}}$ & 1.03 & 1.02 \\
\hline
\end{tabular}

\section{Conclusions}

In the present investigation, we have studied the formation and stability of amorphous phase in $\mathrm{Al}_{50} \mathrm{Cu}_{45} \mathrm{Ti}_{5}$ and $\mathrm{Al}_{45} \mathrm{Cu}_{45} \mathrm{Ti}_{10}$ rapidly quenched alloys. The DSC curve shows a broad complex type of exothermic peak (288$550^{\circ} \mathrm{C}$ ) for $\mathrm{Al}_{50} \mathrm{Cu}_{45} \mathrm{Ti}_{5}$ and a well defined peak around $373^{\circ} \mathrm{C}$ for $\mathrm{Al}_{45} \mathrm{Cu}_{45} \mathrm{Ti}_{10}$ alloy. In the case of $\mathrm{Al}_{50} \mathrm{Cu}_{45} \mathrm{Ti}_{5}$ alloy, amorphous to icosahedral phase transformation has been observed after annealing at $280^{\circ} \mathrm{C}$ for $73 \mathrm{~h}$. Large dendritic growth of icosahedral phase along with $\alpha-\mathrm{Al}$ phase have been found. Annealing of $\mathrm{Al}_{50} \mathrm{Cu}_{45} \mathrm{Ti}_{5}$ alloy at $400^{\circ} \mathrm{C}$ for $8 \mathrm{~h}$ results in formation of $\mathrm{Al}_{3} \mathrm{Ti}$ type phase. $\mathrm{Al}_{45} \mathrm{Cu}_{45} \mathrm{Ti}_{10}$ amorphous alloy is more stable in comparison to $\mathrm{Al}_{50} \mathrm{Cu}_{45} \mathrm{Ti}_{5}$ alloy and after annealing at $400^{\circ} \mathrm{C}$ for $8 \mathrm{~h}$, it also transforms to $\mathrm{Al}_{3} \mathrm{Ti}$ type phase. However, this alloy does not show amorphous to icosahedral phase transformation.

\section{Acknowledgements}

The authors are grateful to the Ministry of Non-Conventional Energy Sources and the Department of Science and Technology, for providing the financial support. Authors are also thankful to $\operatorname{Dr}$ A M Awasthi, Inter University Consortium, Indore, for useful discussions and providing DSC facilities for the present work. One of the authors (DKM) gratefully acknowledges the financial support provided by the Council of Scientific and Industrial Research (CSIR).

\section{References}

Aronim A S, Abrosimove G E, Gurov A F, Yu and Kornova V 2001 Mater. Sci. \& Eng. A304-306 375

Elser V 1985 Phys. Rev. B328 4892

Fasi T K, Zhang T, Inoue A, Yang Y S, Kim I B and Kim V H 2001 Mater. Sci. \& Eng. A304-306 892

Greer A L 2001 Mater. Sci. \& Eng. A304-306 68

Hambleton R, Jones H and Rainforth W M 2001 Mater. Sci. \& Eng. A304-306 524

Holzer J C and Kelton K 1991 Acta Metallogr. 391833

Inoue A 2001 Mater. Sci. \& Eng. A304-306 1

Li C, Saida J, Matsusheta M and Inoue A 2001 Mater. Sci. \& Eng. A304-306 308

Misra D K, Tiwari R S and Srivastava O N 2001 Cryst. Res. Technol. 36419

Murty B S, Naik M O, Mohan M Rao and Ranganathan S 1992 Mater. Forum 1619 
Popescu R, Jianu A, Manciu M, Nicula R and Manaila R 1995 J. Alloys \& Compounds 221240

Raynor G V 1994 Progr. Metal. Phys. 11

Satyanarayana K G, Ojha S N, Naresh Nath Kumar D and Shastry G V S 2001 Mater. Sci. \& Eng. A304-306 627

Shao G, Tsaiu P Kiropoulos and Miodownik A P 1995 Int. J. Rapid Solidification 913
Smith J F and Ray A E 1957 Acta Crystallogr. 10169

Srinivasan D and Chattopadhayay K 2001 Mater. Sci. \& Eng. A304-306 534

Tsai A P, Hiranga K, Inoue A, Masumoto T and Chen H S 1999 Phys. Rev. B44 3569

Upadhya R and Tiwari R S 1996 Phys. Status Solidi (a)156 39 